\title{
Minuartio valentinae-Quercetum pyrenaicae: a new Iberian broad-leaved oak forest in the eastern coastal mountains and their seral plant communities
}

\author{
Beatriz Vilches de la Serna (*), Hugo Merle (**), María Ferriol (**), \\ Daniel Sánchez-Mata (*) \& Rosario G. Gavilán (*)
}

\begin{abstract}
Vilches de la Serna, B., Merle, H., Ferriol, M., Sánchez-Mata, D. \& Gavilán, R.G. Minuartio valentinaeQuercetum pyrenaicae: a new Iberian broad-leaved oak forest in the eastern coastal mountains and seral plant communities. Lazaroa 34: 209-217 (2013).

The study of Quercus pyrenaica forests in eastern areas of the Iberian Peninsula has differentiated a set of relevés from Castellón. They are located in subhumid sites in the upper mesomediterranean to low supramediterranean thermotype territories of Sierra de Espadán, in the Valenciano-Tarraconense biogeographical sector. A new forest Minuartio valentinaeQuercetum pyrenaicae is therefore described here, together with its main seral communities.
\end{abstract}

Keywords: broad-leaved oak forests, Mediterranean vegetation, new association, community ecology, Sierra de Espadán.

Resumen: Vilches de la Serna, B., Merle, H., Ferriol, M., Sánchez-Mata, D. \& Gavilán, R. G. Minuartio valentinaeQuercetum pyrenaicae: una nueva serie de vegetación de los melojares de las montañas levantinas costeras y sus comunidades seriales. Lazaroa 34: 209-217 (2013).

El estudio de los bosques de Quercus pyrenaica del centro y este ibérico ha discriminado un conjunto de inventarios procedentes de Castellón. Están situados en emplazamientos de termotipos mesomediterráneo superior-supramediterráneo inferior y ombrotipo subhúmedo de la Sierra de Espadán, incluidos en el sector biogeográfico Valenciano-Tarraconense. Así, se describe la nueva asociación de melojares Minuartio valentinae-Quercetum pyrenaicae y las comunidades seriales que forman una nueva serie de vegetación para la Península Ibérica.

Palabras clave: Bosques marcescentes, melojares, vegetación mediterránea, nueva asociación, ecología de las comunidades, Sierra de Espadán.

\section{INTRODUCTION}

The distribution of the marcescent Pyrenean oak on the Iberian Peninsula is concentrated mainly in sites with a sub-Mediterranean climate (moderate or compensated summer drought) in the northwest. This, together with its preference for siliceous soils (less common in the east), means that only reduced samples remain in eastern mountain zones, and usually in protected areas surrounded by evergreen (generally basophile) vegetation. They appear over $1000 \mathrm{~m}$ asl and have traditionally been included in the supra-mediterra- nean association Cephalanthero rubrae-Quercetum pyrenaicae. All are at risk of local extinction due to their level of isolation (mainly edaphic) and fragmentation (PÉREZ BADÍA, 2003). The Prades mountains in Catalonia, Pina, Penyagolosa, Castielfabib, and Tuéjar in Valencia are sites for which there is bibliographic evidence of the presence of this oak forest (BRAUN-BlanQueT, 1934; FonT QueR, 1934; Bolòs, 1967; VigO, 1968; COSTA \& al., 1985; Herreros, 2010; Roselló, 1994; Mateo \& Aguilella, 1990), and Prades and Penyagolosa are its best representations in the eastern Iberian peninsula. Its composition is high in ne-

* Departamento de Biología Vegetal II. Facultad de Farmacia. Universidad Complutense. E-28040 Madrid, Spain. E-mail: bvilches@ucm.es; dsmata@ucm.es; rgavilan@ucm.es

** Instituto Agroforestal Mediterráneo. Universidad Politécnica de Valencia. Camino de Vera 14. Valencia 46022. Spain. Email: humerfa@upvnet.upv.es; mafermo@upvnet.upv.es 
moral herbs, and often includes other phanerophytes in the arboreal stratum with which it is in contact, mainly Pinus sylvestris s.l., in addition to Juniperus communis. Different Cytisus and Erica appear frequently in the shrub layer, also accompanied by the typical spiny border shrubs Crataegus monogyna or Prunus spinosa.

Although the vegetation of the Sierra de Espadán has been studied, as a whole, by various authors (BEltrán, 1911; Rivas Goday \& BorJa, 1961; Bolòs, 1967, 1975; Bolòs \& ViGO, 1979; Mateo \& Aguilella, 1990), its oak forests are the least studied of all those on the eastern Iberian Peninsula. This can be explained by its isolated location and relatively difficult access, and partly because historically this has been a managed area, as it is located in cooler locations that are ideal for farming (MERLE \& FERRIOL, 2008), reducing the forest area, currently under regeneration.

The Espadán Triassic mountain range, although not very high in altitude (highest peak: La Rápita at $1106 \mathrm{~m}$ asl) captures more rain and humidity than nearby territories. Its NW-SE orientation leads to an annual average rainfall of over $600 \mathrm{~mm}$ on the lower slopes, in addition to the contribution of the frequent mists in the area. Espadán soils comprise mainly Buntsandstein sandstones and argilites, characterized by neutral $\mathrm{pH}$, and locally by the formation of deep argillic horizons that allow good water reserves. Both these factors are instrumental in making cork oak the main vegetation in the mountain range, with a predominance of maritime pine (Pinus pinaster s.l.) in drier areas. Heathlands are found on the forest fringes; they are the main substitution shrubs for cork oak forests (COSTA \& al., 1985) in sites with a cooler microclimate and for Quercus pyrenaica formations. Several authors have highlighted the special floristic character of this site where Temperate, Iberian-Moroccan and endemic species converge (RIVAS GODAY \& BORJA, 1961; MATEO \& AGUILELLA, 1990); some have also delimited an independent chorologic element inside the Valenciano-Tarraconense sector, supported by endemics such as Minuartia valentina, Centaurea paui, Dianthus multiaffinis or Biscutella calduchii (O. Bolòs \& Masclans) Mateo \& M.B. Crespo (Roselló, 1994; Costa \& al., 1985).

The main aim of our paper is to describe a new association of broad-leaved oak forests in the Sierra de Espadán. This objective was developed as part of a larger study of all the Quercus pyrenaica forests on the Iberian Peninsula. The results of this study emphasised the significant floristic difference between the forests described here and the rest, even when they appear at similar altitudes and bioclimatic belts. We have also analysed -from a purely phytosociological point of view- the following main seral plant communities: heathlands appearing as forest fringes or as a substitution plant community when the forest is destroyed; and shrublands representing a more degraded stage.

\section{MATERIALS \& METHODS}

We compiled a data set of published relevés on Quercus pyrenaica forests in eastern areas of the Iberian Peninsula (Table 1). These relevés were pre-

Table 1

Summary of data gathering according to the locations studied

\begin{tabular}{|c|c|c|c|c|c|}
\hline No. Original assignment & \multirow{2}{*}{$\begin{array}{l}\text { Locality } \\
\text { Guadarrama }\end{array}$} & \multirow{2}{*}{$\begin{array}{l}\text { Province } \\
\text { Madrid }\end{array}$} & \multirow{2}{*}{$\begin{array}{l}\begin{array}{l}\text { Distance } \\
\text { to coast }\end{array} \\
480 \mathrm{~km}\end{array}$} & \multirow{2}{*}{$\begin{array}{l}\text { Altitude } \\
1170-1500 \mathrm{mosl}\end{array}$} & \multirow{2}{*}{$\begin{array}{l}\text { References } \\
\text { FERNÁNDEZ-GONZÁLEZ, } 1991\end{array}$} \\
\hline 1 Luzulo fors & & & & & \\
\hline 2 Luzulo forsteri-Quercetum & Ayllón & Guadalajar & $430 \mathrm{~km}$ & $960-1350$ mosl & \\
\hline 3 Luzulo forsteri-Quercetum & Albarracín & Teruel & $235 \mathrm{~km}$ & 1500 & $\mathrm{BAl}$ \\
\hline 4 Luzulo forsteri-Quercetum & Boniches & Cuenca & $170 \mathrm{~km}$ & 00 mosl & LÓPE \\
\hline Luzulo forsteri-Quercetum & Ranera & & & $1280-1380$ mosl & \\
\hline 5 Cephalanthero-Quercetum & Penyagolosa & Castellón & $58 \mathrm{~km}$ & 00 mosl & VIG \\
\hline 6 Cephalanthero-Quercetum & Prades & Tarragona & $27 \mathrm{~km}$ & 950-1050 mosl & $\begin{array}{l}\text { BRAUN-BlanQUET, 1934; } \\
\text { FoNT QUER, 1934, Bolòs, } 1967\end{array}$ \\
\hline 7 Cephalanthero-Quercetum s.l & Espadán & Castellón & $35 \mathrm{~km}$ & 900-1106 mosl & Merle \& Ferriol, 2008 \\
\hline
\end{tabular}


viously analysed to check the relationships between central and eastern Quercus pyrenaica forests (VILCHES \& al., 2013). We used Principal Components Analysis (PCA) on the site-by-species matrix containing presence-absence values to display the compositional variation among the Quercus pyrenaica woodlands in the study. Using indicator species analyses with site group combinations ('multipatt' function of the R package 'indicspecies') we determined the indicator species of each massif, in addition to the common species in forests belonging to those different massifs. The number and identity of the indicators suggest how the different geographical locations could be related.

For the seral communities we studied the data published in the Catalano-Valenciano biogeographical subprovince (Valenciano-Tarraconense sector), which includes: BRAUN-BlanQuET (1940),ZELLER (1959), Bolòs (1967) Mateo (1983), MateO \& MANSANET (1982), Costa \& al. (1985), GARCÍAFAYOS (1991), MERLE \& FERRIOL (2008).

We have followed the taxonomic nomenclature proposed by the published volumes of Flora Iberica (CASTROVIEJO \& al., 1986-2013) if the authority is not indicated; and the compilation of the Euro+Med PlantBase (2006-2013) for the rest. In addition we have followed RIVAS-MARTínEZ \& al. (2007, 2011b) proposals for the biogeographical and bioclimatological characterisation of the studied forest.

\section{RESULTS \& DISCUSSION}

\section{Minuartio valentinae-Quercetum pyrenaicae} ass. nova hoc loco

[Holotypus ass. Table 2, rel. 2; (Merle \& Ferriol, 2008)]

The first axis of the PCA (Figure 1) separated the pre-coastal relevés with the lowest altitudes Sierra de Espadán (downward triangles)- in the most positive part of the diagram, with the most central relevés -Sierra de Guadarrama (solid circles) and Sierra de Ayllón (upward triangles)- in the negative part. The relevés assigned to Cephalanthero-Quercetum pyrenaicae O. Bolòs \& Vigo in O. Bolòs 1967 and Luzulo-Quercetum pyrenaicae Rivas-Martínez 1964 in the eastern localities of Cuenca, Teruel, Valencia and Catalonia appeared only in the middle, leaving Penyagolosa, the highest peak in the upper section. Thus the first

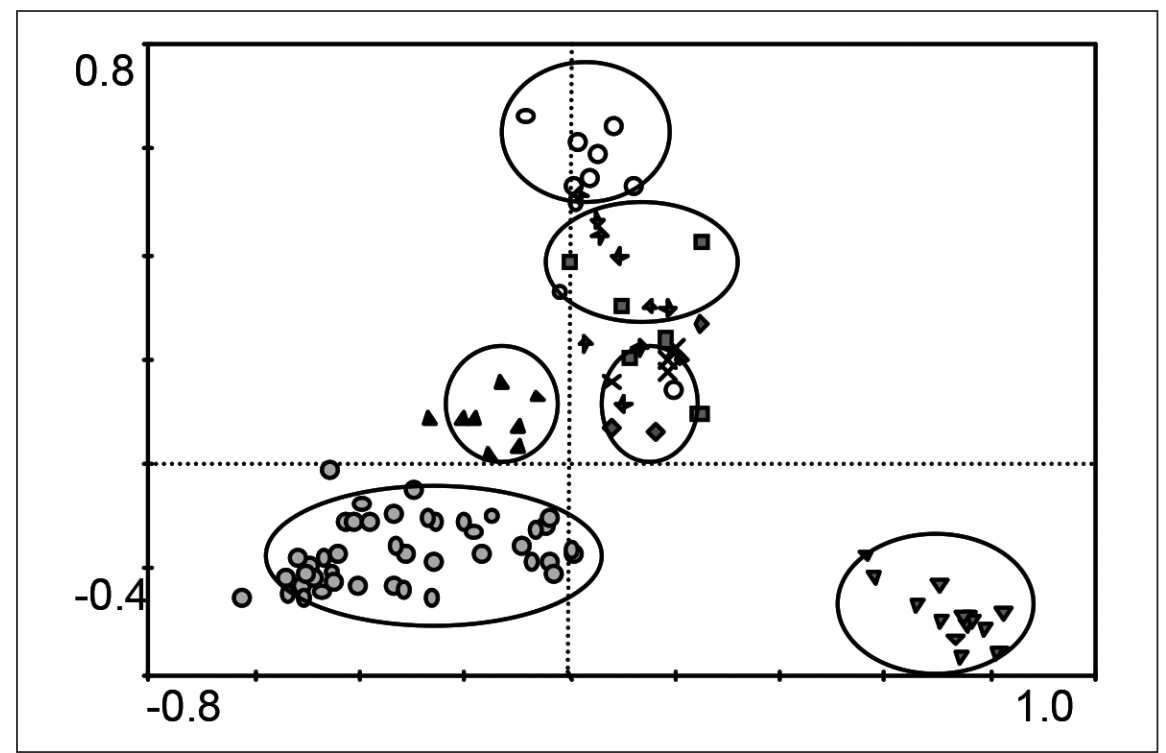

Figure 1. - First two axes of the Principal Component Analysis carried out with data from Sierra de Espadán (downward triangles), Sierra de Prades (solid boxes), Sistema Ibérico: Penyagolosa (open circles), Albarracín Massif (stars) and Serranía de Cuenca: Boniches (X-marks), Ranera (diamonds), Sistema Central: Ayllón (upward triangles), Guadarrama (solid circles). 
Table 2

Minuartio valentinae-Quercetum pyrenaicae ass. nova (Quercion pyrenaicae, Quercetalia roboris, Querco-Fagetea)

\begin{tabular}{lccccccccccccccc}
\hline Cover (\%) & 100 & 100 & 100 & 100 & 100 & 100 & 100 & 100 & 100 & 100 & 100 & 100 & 100 & 100 & 100 \\
Slope (\%) & 40 & 30 & 35 & 35 & 35 & 20 & 30 & 30 & 30 & 30 & 30 & 30 & 30 & 30 & 30 \\
Exposure & $\mathrm{N}$ & $\mathrm{N}$ & $\mathrm{N}$ & $\mathrm{N}$ & $\mathrm{N}$ & $\mathrm{N}$ & $\mathrm{N}$ & $\mathrm{N}$ & $\mathrm{N}$ & $\mathrm{N}$ & $\mathrm{N}$ & $\mathrm{N}$ & $\mathrm{N}$ & $\mathrm{N}$ & $\mathrm{N}$ \\
Area $\left(\mathrm{m}^{2}\right)$ & 100 & 50 & 50 & 50 & 50 & 50 & 50 & 50 & 50 & 50 & 50 & 50 & 50 & 50 & 50 \\
Relevé N. & 1 & 2 & 3 & 4 & 5 & 6 & 7 & 8 & 9 & 10 & 11 & 12 & 13 & 14 & 15 \\
\hline
\end{tabular}

Characteristics

Quercus pyrenaica

Quercus pyrenaica shrub

Hedera helix

Hieracium glaucinum

Luzula forsteri

Moehringia trinervia

Biscutella calduchii

Minuartia valentina

Polypodium cambricum

Hieracium amplexicaule

Erica arborea

Asplenium onopteris

Rubia peregrina

Galium maritimum

Quercus suber

Quercus rotundifolia

Daphne gnidium

Lonicera implexa

Companions

Brachypodium retusum

Rubus ulmifolius

Rosa pouzinii

Ulex parviflorus

Helianthemum origanifolium *

Carex muricata

Euphorbia flavicoma

Prunus spinosa

Pinus pinaster s.l.

Teucrium chamaedrys

Crataegus monogyna

Geranium robertianum

Cistus albidus

Phleum phleoides

Viola alba

Festuca durandoi

Sedum sediforme

Vicia tenuifolia

Silene inaperta

Orobanche alba

Cephalanthera rubra

Thapsia villosa

Hieracium sabaudum

Pteridium aquilinum

$\begin{array}{ccccccccccccccc}5 & 5 & 5 & 5 & 5 & 5 & 5 & 4 & 5 & 5 & 5 & 5 & 3 & 5 & 4 \\ 5 & 3 & 2 & 3 & 4 & 4 & 5 & 4 & 5 & 4 & 3 & 3 & 5 & 3 & 2 \\ + & 1 & + & 1 & + & 1 & + & 1 & . & + & 1 & . & 2 & 1 & 4 \\ 2 & + & + & . & . & . & + & 1 & . & . & + & . & . & . & . \\ + & 1 & . & . & . & + & . & 1 & + & . & 1 & . & + & + & + \\ . & . & . & . & . & . & + & + & + & . & . & . & . & . & . \\ 1 & 1 & 1 & 1 & 1 & + & + & + & + & + & + & + & + & + & . \\ 5 & 4 & 3 & 5 & + & + & + & . & 1 & 2 & 2 & 3 & 3 & 3 & 2 \\ + & + & . & . & . & . & . & . & + & + & . & + & . & + & + \\ + & . & . & . & . & . & + & . & + & . & . & . & . & + & + \\ 2 & 2 & 1 & 2 & 2 & 3 & 2 & 1 & 1 & 2 & 2 & 1 & + & + & + \\ 1 & 1 & 1 & 1 & + & + & 1 & 1 & 1 & 1 & 1 & 1 & 1 & 1 & 3 \\ + & + & 1 & + & 1 & 1 & 1 & 1 & 1 & + & + & + & + & + & + \\ + & + & + & + & + & + & + & 1 & 1 & + & 1 & 1 & + & + & + \\ 1 & 1 & 1 & . & 1 & 1 & 1 & 2 & + & + & . & 1 & + & . & 1 \\ . & . & . & 1 & 1 & . & 1 & 2 & + & . & . & + & + & . & . \\ . & . & . & . & . & + & . & + & 1 & 1 & + & + & . & . & . \\ + & + & . & + & . & . & . & . & . & . & . & . & . & + & +\end{array}$

Other species: Asplenium trichomanes, Antirrhinum barrelieri, Cistus salviifolius + in 9; Dactylis glomerata + in 12; Galium idubedae + in 13 and Scrophularia sciophila + in 14 .

Localities: All relevés from Sierra de Espadán between 900-1106 m asl. Holotypuss ass. rel. 2

* Helianthemum origanifolium: H. marifolium subsp. origanifolium 
PCA axis could be interpreted as a continentalityoceanity gradient, with relevés from the Sierra de Espadán near the coast, and clearly separated from the relevés of the central Iberian Peninsula. The second axis could be related to a Mediterranean (aridity) gradient, with relevés with shorter or compensated summer drought located in the most positive part, clearly separated from the Sierra de Espadán and Sistema Central, which undergo higher summer dryness. Most of these forests are located at higher altitudes than the coastal Sierra de Espadán (Figure 1), where retention of clouds formed by evaporation from the Mediterranean Sea becomes a factor of vital importance to compensate aridity. Precipitation and fog increase the atmospheric humidity of these mountains, where it is common to find ferns and other cryptogrammic species such as Asplenium onopteris, Polypodium cambricum or Polypodium vulgare (MATEO \& Aguilella, 1991).

The Sierra de Espadán generated the maximum number of exclusive indicator species, including a high number of endemisms that separated it from relevés ascribed to Cephalanthero-Quercetum pyrenaicae from Penyagolosa and Prades (VILCHES \& al., 2013). Both mountains have almost three months of frost risk in winter, and both Quercus pyrenaica forests are related to Pinus sylvestris s. . and Cistion laurifolii seral communities. Only the pre-coastal location of Prades (Catalonia) shares certain species with Espadán -such as Rosa pouzinii, Cistus albidus or Asplenium onopteris- in addition to some thermophilous and calcareous species, although the analysis (Figure 2) confirmed a differentiated floristic composition of the latter. In fact this difference was also apparent when this community was compared to the whole Iberian Peninsula (VILCHES \& al., in press).

Minuartio valentinae-Quercetum pyrenaicae corresponds to silicicolous subhumid forests of Quercus pyrenaica, appearing over rodenos in the upper mesomediterranean to lower supramediterranean belts of the Sierra de Espadán (Castellón). It is found in sites with reduced continentality and increased humidity due to crypto-precipitations and also to the deep limy soils. Its distribution is thus reduced and localized, specifically on the northern slope of the highest peak: La Rápita (as indicated by Mateo \& Aguilella, 1990; Roselló, 1994). The territory has been cultivated for centuries, and some individuals of Quercus pyrenaica can be found growing on abandoned terraces. The forests have a strong level of regeneration and usually include evergreen phanerophytes from the forests with which they are in contact, such as Quercus suber, Quercus rotundifolia and Pinus pinaster s.l., in addition to shrubs (Erica arborea, Ulex parviflorus, Prunus spinosa). Quercetea ilicis species are widely represented in these forests, in contrast with the Quercus pyrenaica locations of the supramediterranean Cephalanthero-Quercetum pyrenaicae (Penyagolosa or Prades), which have an increased Eurosiberian species composition (VILCHES \& al., 2013). Thus the absence of some species such as Astragalus glycyphyllos, Primula veris subsp. columnae, Veronica officinalis, Poa nemoralis, Campanula trachelium and Lapsana communis, together with its chorology and dynamism, differentiate it from Cephalanthero-Quercetum pyrenaicae.

As is known, Pyrenean oak requires a minimum annual rainfall of $600 \mathrm{~mm}$ to become established, as well as a site that compensates the Mediterranean summer drought (COSTA, 1997). The timing of the rainfall in this area (autumnspring-winter-summer) facilitates a faster recovery of water reserves (Roselló, 1994), enough for Minuartio-Quercetum pyrenaicae to grow in the most humid sites throughout the entire Sierra de Espadán, specifically sub-humid locations (Vall de Almonacid, 670 mm; Bolòs \& Vigo, 1979; NinYEROLA \& al., 2005). There is an absence of most of the drought tolerant species of the Valenciano-Tarraconense sector such as Phillyrea angustifolia (including the subhumid Ph. latifolia), Rhamnus alaternus or Pistacia lentiscus; but also a lack of thermophilic shrubs frequent in other mesomediterranean Quercus pyrenaica forests (Arbutus unedo, Viburnum tinus).

On southern slopes or in more exposed areas, these forests come into contact with the Valencian cork forests of Asplenio onopteridis-Quercetum suberis, and also with Hedero-Quercetum rotundifoliae in drier areas. Our community shares more species with the former, mainly in the understory, where the rocky silicicolous substrate allows the 
Table 3

Hedero helicis-Ericetum arboreae (Costa, Peris, Figuerola \& Stübing 1985) Rivas-Mart. \& al. 2011 (Pistacio lentisci-Rhamnetalia alaterni, Ericenion arboreae, Quercetea ilicis)

\begin{tabular}{lcccccccc}
\hline Cover $(\%)$ & 100 & 100 & 100 & 100 & 100 & 100 & 100 \\
Slope $(\%)$ & 30 & 30 & 30 & 30 & 30 & 30 & 30 \\
Exposure & $\mathrm{N}$ & $\mathrm{N}$ & $\mathrm{N}$ & $\mathrm{N}$ & $\mathrm{N}$ & $\mathrm{N}$ & $\mathrm{N}$ \\
Area $\left(\mathrm{m}^{2}\right)$ & 50 & 50 & 50 & 50 & 50 & 50 & 50 \\
Relevé N. & 1 & 2 & 3 & 4 & 5 & 6 & 7 \\
\hline
\end{tabular}

\begin{tabular}{|c|c|c|c|c|c|c|c|}
\hline \multicolumn{8}{|l|}{ Characteristics } \\
\hline Erica arborea & 4 & 5 & 5 & 5 & 4 & 4 & 4 \\
\hline Asplenium onopteris & + & + & + & + & + & + & + \\
\hline Rubia peregrina & . & + & + & + & + & 1 & + \\
\hline Quercus rotundifolia & . & 1 & + & 1 & 1 & . & 1 \\
\hline Quercus suber & 1 & . & 1 & + & 1 & + & 1 \\
\hline Galium maritimum & 1 & + & + & . & + & + & $\cdot$ \\
\hline Lonicera implexa & · & . & + & 1 & . & 2 & \\
\hline Daphne gnidium & 1 & 1 & . & . & . & . & \\
\hline \multicolumn{8}{|l|}{ Companions } \\
\hline Brachypodium retusum & 3 & 4 & 4 & 3 & 3 & + & 1 \\
\hline Rosa pouzinii & 1 & + & + & + & + & 1 & 1 \\
\hline Biscutella calduchii & + & + & + & + & + & + & + \\
\hline Crataegus monogyna & + & . & + & 1 & + & 1 & + \\
\hline Euphorbia flavicoma & + & + & + & + & + & . & + \\
\hline Minuartia valentina & . & + & 1 & 1 & . & + & $T$ \\
\hline Rubus ulmifolius & 2 & . & . & 1 & + & + & 1 \\
\hline Cistus albidus & 1 & 1 & . & 1 & . & 1 & + \\
\hline Ulex parviflorus & 2 & 2 & 1 & . & + & 1 & . \\
\hline Prunus spinosa & . & 1 & 1 & 1 & + & 1 & . \\
\hline Helianthemum origanifolium $*$ & . & + & + & + & . & + & . \\
\hline Hedera helix & r & . & . & . & 1 & + & 1 \\
\hline Polypodium cambricum & . & . & + & $\cdot$ & . & + & + \\
\hline Pinus pinaster s.l. & 1 & . & + & . & 2 & . & \\
\hline Quercus pyrenaica shrub & . & . & + & . & . & . & + \\
\hline Vicia tenuifolia & $\cdot$ & . & + & . & . & . & + \\
\hline Luzula forsteri & - & · & . & 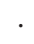 & + & + & \\
\hline Hieracium glaucinum & . & . & + & 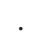 & + & . & \\
\hline Galium idubedae & 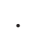 & . & + & + & . & . & \\
\hline Viola alba & . & . & + & + & . & . & \\
\hline Quercus pyrenaica & • & 1 & 1 & . & . & . & \\
\hline Phleum phleoides & + & + & . & . & . & . & \\
\hline
\end{tabular}

Other species: Sedum sediforme and Thapsia villosa + in 2; Cistus salviifolius 1 in 4; Asplenium trichomanes, Scrophularia tanacetifolia, Geranium robertianum, Hieracium amplexicaule and Antirrhinum barrelieri + in 6 . Localities: All relevés from Sierra de Espadán (Pico La Rápita) between 900-1106 m.a.s.1.

* Helianthemum origanifolium: H. marifolium subsp. origanifolium

inclusion of Minuartia valentina and other related Espadán endemisms such as Biscutella calduchii or Scrophularia tanacetifolia; it also shares the heathland fringe community described below.

Hedero helicis-Ericetum arboreae (Costa, Peris, Figuerola \& Stübing 1985) Rivas-Mart. \& al. 2011 (=Cytiso villosi-Ericetum arboreae Costa, Peris, Figuerola \& Stübing 1985 non Zéller 1959)

We agree with CosTA \& al. (1985) regarding the floristic composition of seral scrub plant communities that form part of the vegetation series of Minuartio-Quercetum pyrenaicae. Hedero-Ericetum is not only the first degraded plant community of Asplenio-Quercetum suberis in the Sierra de Espadán; it is also present as a seral state of Minuartio-Quercetum, although impoverished in scrubs such as Cytisus villosus or Ruscus aculeatus (MERLE \& FERRIOL, 2008). It is found in shady areas where soils retain enough water, and has a coastal influence in the upper mesomediterranean to lower supramediterranean bioclimatic belt. They are included in Quercetea ilicis and not in Cytisetea as it could be expected (RIVAS-MARTíNEZ \& al., 2011; GAVILÁN \& al., 2011).

We followed the criteria of RIVAS-MARTínEZ \& al. (2011) to distinguish Espadán heathlands (Cytiso villosi-Ericetum arboreae Costa, Peris, Figuerola \& Stübing 1985), from the species reported by ZELLER (1959) to describe a similar plant community in Catalonia dominated by Erica arborea and Cytisus villosus, together with other brooms such as Teline monspessulana and Cytisus scoparius subsp. reverchonii. Espadán heathlands are lacking most of these species, although may include Cytisus villosus. Moreover, as mentioned above, in the territory of Minuartio-Quercetum pyrenaicae there is an absence of drought-tolerant and thermophilic species inside the HederoEricetum, such as Ruscus aculeatus, Smilax aspera, Clematis flammula, etc. (Table 2).

Ulici parviflorae-Cistetum albidi ass. nova hoc loco [Holotypus ass. Table 4, rel. 1; (Merle \& Ferriol, 2008)]

They represent rockrose-gorse shrublands that appear in a more degraded stage than HederoEricetum arboreae. Of all the associations des- 
Table 4

Ulici parviflorae-Cistetum albidi ass. nova (Cistion ladaniferi, Lavanduletalia stoechadis, Cisto-Lavanduletea)

\begin{tabular}{lccccccccc}
\hline Cover $(\%)$ & 100 & 100 & 100 & 100 & 100 & 100 & 100 & 100 \\
Slope & 20 & 30 & 30 & 30 & 30 & 30 & 30 & 30 \\
Exposure & $\mathrm{N}$ & $\mathrm{N}$ & $\mathrm{N}$ & $\mathrm{N}$ & $\mathrm{N}$ & $\mathrm{N}$ & $\mathrm{N}$ & $\mathrm{N}$ \\
Area $\left(\mathrm{m}^{2}\right)$ & 100 & 50 & 50 & 50 & 50 & 50 & 50 & 50 \\
Relevé N. & 1 & 2 & 3 & 4 & 5 & 6 & 7 & 8 \\
\hline
\end{tabular}

\begin{tabular}{|c|c|c|c|c|c|c|c|c|}
\hline Characteristics & & & & & & & & \\
\hline Ulex parviflorus & 2 & 4 & 4 & 3 & 5 & 4 & 3 & 2 \\
\hline Cistus albidus & 2 & 3 & 3 & 4 & 3 & 3 & 3 & 4 \\
\hline Cistus salviifolius & + & 1 & 1 & $v^{\prime}$ & 1 & & . & \\
\hline Companions & & & & & & & & \\
\hline Asplenium onopteris & + & + & + & + & + & + & + & + \\
\hline Biscutella calduchii & . & + & + & + & + & + & + & + \\
\hline Galium maritimum & . & + & + & + & + & + & + & + \\
\hline Trifolium campestre & + & . & 1 & + & + & + & + & + \\
\hline Sedum sediforme & + & . & + & + & + & + & + & + \\
\hline Brachypodium retusum & 5 & 4 & 3 & 4 & 3 & 4 & . & 3 \\
\hline Euphorbia flavicoma & + & + & + & + & . & . & + & 1 \\
\hline Prunus spinosa & 1 & + & - & 1 & + & 1 & . & 1 \\
\hline Helianthemum & & & & & & & & \\
\hline origanifolium $*$ & + & + & + & . & + & + & + & . \\
\hline Trifolium arvense & + & . & + & . & . & + & 1 & 1 \\
\hline Rubus ulmifolius & 1 & 1 & 1 & . & . & . & 1 & 1 \\
\hline Geranium robertianum & 1 & . & + & . & . & + & + & + \\
\hline Dactylis glomerata & + & . & + & . & + & + & . & + \\
\hline Quercus rotundifolia & & 1 & + & . & + & + & 1 & . \\
\hline Rosa pouzinii & 2 & + & $\cdot$ & $\cdot$ & + & 1 & - & . \\
\hline Thapsia villosa & 2 & 2 & 1 & 1 & . & . & . & . \\
\hline Senecio lividus & 1 & + & + & + & . & . & . & . \\
\hline Daphne gnidium & 1 & + & + & + & . & - & . & . \\
\hline Galium idubedae & $\cdot$ & . & $\cdot$ & . & . & + & + & 1 \\
\hline Hedera helix & 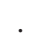 & . & . & . & + & . & + & 2 \\
\hline Minuartia valentina & . & + & 1 & . & . & . & . & 1 \\
\hline Quercus suber & + & . & . & . & + & 1 & . & . \\
\hline Phleum phleoides & - & . & + & . & + & + & . & . \\
\hline Vicia tenuifolia & $\cdot$ & . & - & . & . & . & + & 2 \\
\hline Lonicera implexa & . & . & . & . & . & . & 1 & + \\
\hline Silene inaperta & . & . & - & + & . & . & . & + \\
\hline Rubia peregrina & + & . & . & . & . & e & . & + \\
\hline Antirrhinum barrelieri & . & . & - & . & . & + & 1 & \\
\hline Erica arborea & & 2 & . & . & . & + & . & \\
\hline Polypodium cambricum & & . & + & . & 1 & . & . & \\
\hline Hieracium amplexicaule & + & . & + & . & . & . & . & \\
\hline
\end{tabular}

Other species: Crataegus monogyna 1 in 1 ; Pteridium aquilinum + in 3; Quercus pyrenaica 1 in 5; Pinus pinaster 1, Asplenium trichomanes + in 6; Festuca durandoi 1 in 7; Scrophularia sciophila and Carex muricata + in 8. Localities: All relevés from Sierra de Espadán (Pico La Rápita) between 900-1106 m asl. Holotypus ass. rel. 4. * Helianthemum origanifolium: H. marifolium subsp. origanifolium cribed in the area, the relevés included in the new association Ulici-Cistetum are close to those of Pino pinastri-Cistetum salvifolii Bolòs 1967 given by COSTA \& al. (1985) and recently synonymized by Rivas-MARTínez \& al. (2002) to Calicotomo spinosae-Cistetum crispi Br.-B1. 1940. The original relevés given by BRAUN-BLANQUETin 1940 showed the dominance of Calicotome spinosa, Cistus crispus, and even Erica cinerea in Catalonia (on granitic soils). Bolòs (1967) included maritime pine (Pinus pinaster s. l.), Lavandula stoechas and Erica arborea to the set, and indicated in a previous work the enormous local variability of this association, in which he suggested including gorse bushes with various Cistaceae that appeared in Espadán and neighbouring mountains (BoLÒs, 1957; RIVAS-MARTíNEZ, 1979). In our case, the community lacks these species (Calicotome spinosa, Cytisus villosus or Lavandula stoechas) and is particularly enriched with Rosmarinetea species such as Cistus albidus and Ulex parviflorus.

The absence of thermophilous taxa such as $\mathrm{Ca}$ licotome spinosa or Cistus crispus in Ulici-Cistetum can be also explained in terms of altitude (900-1106 masl), with the latter found at higher altitudes than taxa of Calicotomo-Cistetum. Frequent fires also favour the dominance of Ulex parviflorus and Cistus albidus, which are quite common in some areas of the Sierra de Espadán such as La Rápita (Merle \& FERrIol, 2008).

\section{CONCLUSIONS}

Minuartio valentinae-Quercetum pyrenaicae can be framed perfectly in the Quercion pyrenaicae alliance, which includes mesophytic Quercus pyrenaica forests from the meso- to supramediterranean bioclimatic belts. Previous studies (HERREROS, 2010; VILCHES \& al., 2013) already reflected a clear distinction between this and the adjacent communities, specifically Luzulo forsteri-Quercetum pyrenaicae and Cephalanthero rubrae-Quercetum pyrenaicae.

The series 'Minuartio valentinae-Querco pyrenaicae sigmetum' corresponds to silicicolous subhumid forests of Quercus pyrenaica, appearing 
on rodenos in the upper mesomediterranean to lower supramediterranean bioclimatic belts of the Sierra de Espadán (Valenciano-Tarraconense biogeographical sector). Hedero helicis-Ericetum arboreae and Ulici parviflorae-Cistetum albidii are their main seral plant communities.

\section{ACKNOWLEDGEMENTS}

We want to thank Pru Brooke-Turner the English revision and also to anonymous reviewers for the comments to the manuscript. This paper has been financed by the Madrid Autonomous Government through the research project REMEDINAL2 (S2009/AMB-1783).

\section{SYNTAXONOMICAL SCHEME}

\section{QUERCO-FAGETEA SYLVATICAE Br.-B1. \& Vlieger in Vlieger 1937}

Quercetalia roboris Tx. in Barner 1931

Quercion pyrenaicae Rivas Goday ex Rivas-Mart. 1964

Minuartio valentinae-Quercetum pyrenaicae ass. nova

QUERCETEA ILICIS Br.-Bl. ex A. \& O. Bolòs, 1950

Pistacio lentisci-Rhamnetalia alaterni Rivas-Mart. 1975

Ericion arboreae (Rivas-Mart. ex Rivas-Mart. \& al. 1986) Rivas-Mart. 1987

Hedero helicis-Ericetum arboreae Costa \& al. 1985 in Rivas-Mart. 2011

CISTO-LAVANDULETEA Br.-B1. in Br.B1., Molinier \&Wagner 1940

Lavanduletalia stoechadis Br.-B1. in Br.B1., Molinier \&Wagner 1940 em. Rivas-Martínez 1968

Cistion ladaniferi Br.-Bl. ex A. \& O. Bolòs 1950

Ulici parviflorae-Cistetum albidi ass. nova

\section{REFERENCES}

Barrera, I. - 1983 - Contribución al estudio de la Flora y Vegetación de la $S^{\text {a }}$ de Albarracín - Monogr. Bot. Ibérica 1.

Beltrán, F. - 1911 - Estudios sobre la vegetación de la Sierra de Espadán - Mem. doctoral. Madrid.

Bolòs, O. - 1957- De vegetatione valentina, I - Collect. Bot., 5:528-596

Bolòs, O. - 1967 - Comunidades vegetales de las comarcas próximas al litoral situadas entre los ríos Llobregat y Segura - Mem. R. Acad. Ci. Barcelona 38(1): 1-269.

Bolòs, O. - 1975-De vegetatione valentina, II - An. Inst. Bot. A. J. Cavanilles 32 (2): 447-488.

Bolòs, O. \& Vigo, J. - 1979- Observacions sobre la flora dels Països Catalans - Collect. Bot. 11: 25-89.

Braun-Blanquet, J. - 1934- L'Excursión de la Sigma en Catalogne - Cavanillesia 7: 89-110.

Braun-Blanquet, J., Molinier, R. \& Wagner, H. -1940Prodrome des groupements végétaux. Prodromus der Pflanzengesellschaften.Cisto-Lavanduletea (landes siliceuses à cistes et lavandes). Montpellier.

Castroviejo, S. \& al. -1986-2013 - Flora Ibérica. Plantas vasculares de la Península Ibérica e Islas Baleares. R. Jard. Bot. CSIC, Madrid.

Costa, M., Morla, C., \& Sainz, H. -1997- Los bosques ibéricos. Una interpretación geobotánica. Ed.Planeta, Barcelona.
Costa, M., Peris, J.B., Figuerola, R. \& Stübing, G. 1985 - Los alcornocales valencianos - Doc. Phytosoc. 9: 301-318.

Euro+Med -2006-2013 - Euro+Med PlantBase - the information resource for Euro-Mediterranean plant diversity. http://ww2.bgbm.org/EuroPlusMed/ [05/2013].

Fernández-González, F. - 1991 - Vegetación del Valle del Paular - Lazaroa 12:153-272.

Fuente, V. - 1985- Vegetación orófila del occidente de la provincia de Guadalajara - Lazaroa 8: 123-129.

Font Quer, P. - 1934- El Quercus toza a Catalunya i al Marroc - Cavanillesia 6: 49-58.

García-Fayos, P. - 1991 - La vegetación silicícola de la Sierra Calderona (Comunidad Valenciana) - Lazaroa 12: 317-332.

Gavilán, R.G., Vilches, B. \& Fernández-González, F. 2011 - Syntaxonomical review of Cytisetea scopariostriati communities in central Spain - Lazaroa 32: 29-72.

Herreros, M.J. - 2010 - Contribución al conocimiento de los melojares levantinos (Quercus pyrenaica) en la Península Ibérica - Mem. Lic. (inéd.). Esc. Téc. Sup. Ing. Agrón. Univ. Polit. Valencia.

López, G. - 1976- Contribución al conocimiento fitosociológico de la Serranía de Cuenca I - An. Inst. Bot. A. J. Cavanilles 33:5-87. 
Mateo, G. - 1983- Estudio sobre la flora y vegetación de las sierras de Mira y Talayuelas - Monogr. ICONA, 31 . Madrid.

Mateo, G., \& Aguilella Palasi, A. - 1990 - Aportación al conocimiento fitogeográfico de la Sierra del Espadan (Castellón). (Contribution to the phytogeography of Espadan Mountains (E. Spain) - Folia Bot. Misc. 7: 6780.

Mateo, G. \& Mansanet, J. - 1982 - Sobre la vegetación de la alianza Cistion laurifolii en los alrededores de Valencia - Lazaroa 4: 105-117.

Merle Farinós, H. \& Ferriol Molina, M. -2008 - Some features on Quercus pyrenaica relict forests of Sierra de Espadán (Castellón, Spain) — Lazaroa 29: 125-128.

Ninyerola, M., Pons, X. \& Roure, J.M. -2005 - Atlas Climático Digital de la Península Ibérica. Metodología y aplicaciones en bioclimatología y geobotánica - Univ. Autónoma Barcelona, Bellaterra.

Pérez Badia, R. - 2003 - La vegetación forestal valenciana - An. R. Soc. Econ. Am. País Valencia.

Rivas Goday, S. \& Borja Carbonell, J. - 1961 - Estudio de vegetación y flórula del Macizo de Gúdar y Jabalambre - An. Inst. Bot. A. J. Cavanilles, 19:1-550.

Rivas-Martínez, S. - 1979- Brezales y jarales de Europa occidental (Revisión Fitosociológica de las clases CallunoUlicetea y Cisto-Lavanduletea) - Lazaroa 1: 5-127.
Rivas-Martínez, S., Díaz-Gonzalez, T.E., Fernández-González, F., Izco, J., Loidi, J., Lousã, M. \& Penas, A. 2002 - Vascular plant communities of Spain and Portugal: addenda to the syntaxonomical checklist of 2001 - Itinera Geobot. 15(1-2): 5-922.

Rivas-Martínez, S. \& al. -2007- Mapa de series, geoseries y geopermaseries de vegetación de España [Memoria del mapa de vegetación potencial de España], Parte I - Itinera Geobot. 17: 5-436.

Rivas-Martínez, S. \& al. -2011a - Mapa de series, geoseries y geopermaseries de vegetación de España [Memoria del mapa de vegetación potencial de España], Parte II(2) - Itinera Geobot. 18 (2): 425-800.

Rivas-Martínez, S., Rivas Sáenz, S. \& Penas, A. -2011bWorldwide bioclimatic classification system - Global Geobot. 1: 1-634 + 4 maps.

Roselló, R. - 1994- Catálogo florístico y vegetación de la comarca natural del Alto Mijares (Castellón) - Dip. Castellón. Castellón.

Vigo, J. - 1968 - La vegetació del masis de Penyagolosa - Arx. Sec. Ci. Inst. d'Est. Cat. 37: 1-247.

Vilches, B., De Cáceres, M., Sánchez-Mata, D., Gavilán, R.G. -2013 - Indicator species of broad-leaved oak forests in the eastern Iberian Peninsula - Ecol. Ind. 26: 44-48.

Zeller, W. - 1959- Étude phytosociologique du chêneliege en catalogne - Pirineos 47-50: 3-194.

Received: 4 October 2013

Accepted: 5 December 2013 